\title{
Attenuation of the Pancreatic Beta Cell Response to a Meal Following Hypoglycaemia in Man
}

\author{
B. M. Frier, R. J. M. Corrall, J. P. Ashby, and J. D. Baird \\ Metabolic Unit, University Department of Medicine, Western General Hospital, Edinburgh, Scotland
}

\begin{abstract}
Summary. The plasma concentration of C-peptide, insulin (IRI) and glucose was measured in 9 healthy subjects during insulin-induced hypoglycaemia followed by a meal. Identical observations were made in the same subjects after an equivalent period of fasting without hypoglycaemia (control study). Endogenous secretion of insulin was suppressed following administration of exogenous insulin and this persisted long after the blood glucose concentration had returned to normal. After the meal the mean blood glucose rose to a peak of $8.4 \pm 0.3 \mathrm{mmol} / 1$ (mean $\pm \mathrm{SEM}$ ) at $60 \mathrm{~min}$ and was still raised at $7.5 \pm$ $0.3 \mathrm{mmol} / 1$ at $120 \mathrm{~min}$, compared with a peak value of only $5.1 \pm 0.2 \mathrm{mmol} / \mathrm{l}$ at $30 \mathrm{~min}$ after the meal in the control study. Following hypoglycaemia the mean plasma IRI rose from $8.3 \pm 1.3 \mathrm{mU} / 1$ to a delayed peak of $81.6 \pm 12.7 \mathrm{mU} / 1$ at $60 \mathrm{~min}$ and was $123.5 \pm$ $14 \mathrm{mU} / 1$ at $120 \mathrm{~min}$ post-prandially, compared with a peak of $72.4 \pm 0.5 \mathrm{mU} / \mathrm{l}$ at $30 \mathrm{~min}$ after the meal in the control study. Acute hypoglycaemia may thus induce an abnormal pattern of insulin secretion in response to a meal, with impaired carbohydrate tolerance in normal subjects.
\end{abstract}

Key words: Hypoglycaemia, beta-cell function, Cpeptide, insulin secretion.

The study of insulin secretion during hypoglycaemia in man has, until recently, been restricted by an inability to interpret levels of immunoreactive insulin (IRI) in plasma following the administration of exogenous insulin [1]. Attempts to circumvent this problem have included the induction of hypoglycaemia by the administration of alcohol [2] or fish insulin [1]. Connecting (C-) peptide and insulin are released in equimolar amounts by the pancreatic beta cell. The development of a radioimmunoassay for connecting peptide reactivity (CPR) has made it possible to study the secretion of insulin in vivo during insulin-induced hypoglycaemia [3-6]. We have extended these observations by examining the response of the beta cell to a meal following acute hypoglycaemia.

\section{Subjects and Methods}

Eleven healthy subjects ( 9 male, 2 female), age range $20-29$ years (mean 23.8 years) were studied after an overnight fast. None of the subjects were taking any medications, and all were within ten per cent of their ideal body weight (mean 96 per cent, range 91-102 per cent). The approval of the Medical Ethics Committee was obtained for the study and informed consent was given by each subject.

\section{Hypoglycaemia Study}

Crystalline beef insulin ( 0.15 units $/ \mathrm{kg}$. body weight) was administered as a bolus by rapid intravenous injection and blood samples were taken via an indwelling teflon cannula for estimation of blood glucose [7], plasma CPR [8] (effective detection limit $0.06 \mathrm{nmol} / 1$ ) and plasma IRI levels [9] in the fasting state, and at intervals for 210 min after the injection of insulin. Nine of these subjects were then given a standard mixed meal containing $30 \mathrm{~g}$ protein, $85 \mathrm{~g}$ carbohydrate and $40 \mathrm{~g}$ fat, and blood sampling was continued for a further $120 \mathrm{~min}$. All subjects experienced symptoms and signs of hypoglycaemia between 20 and 30 min (mean $24 \mathrm{~min}$ ) after the injection of insulin.

\section{Control Study}

The same 9 subjects were restudied after an interval of at least one week. The meal was given after an overnight fast plus an equivalent period of fasting without the administration of insulin, and the same parameters were measured. In both studies all subjects consumed the meal within $15 \mathrm{~min}$. 




Fig. 1. Blood glucose concentration (mean \pm SEM) following injection of insulin and in response to a subsequent meal (Hypoglycaemia study) and in response to a meal alone after an equivalent period of fasting (Control study). $\widetilde{C}$ Hypoglycaemia, Control

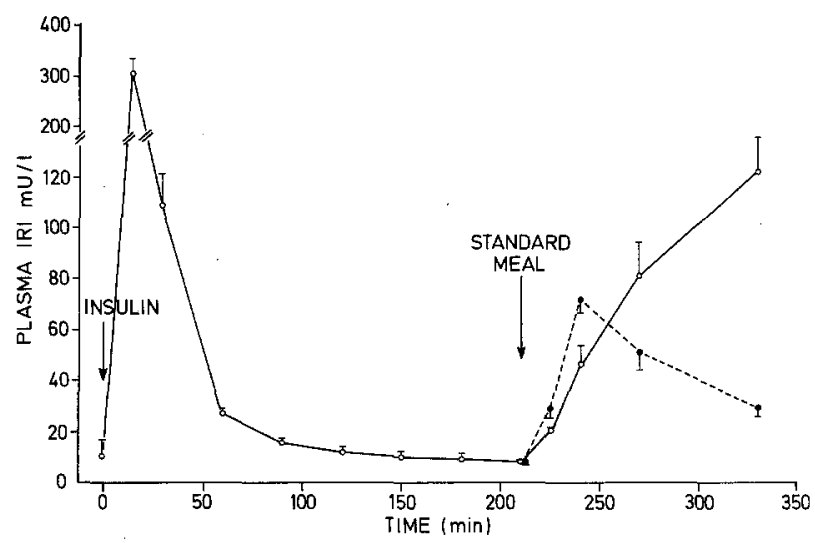

Fig. 3. Plasma IRI concentration (mean \pm SEM) in the hypoglycaemia and control studies. $\delta$ 工 Hypoglycaemia, $\ldots \ldots$ Control

The results are expressed as mean \pm one standard error of the mean (SEM) and statistical significance was estimated using Student's ' $\mathrm{t}$ ' test.

\section{Results}

\section{Blood Glucose}

In the hypoglycaemia study the mean fasting blood glucose fell from $3.9 \pm 0.1$ to $1.2 \pm 0.1 \mathrm{mmol} / 1$ at the time of the acute hypoglycaemic reaction, and regained the fasting level by $150 \mathrm{~min}$ after the injection of insulin (Fig. 1). Following the meal, the mean blood glucose concentration rose to a peak of $8.4 \pm$ $0.3 \mathrm{mmol} / 1$ at $60 \mathrm{~min}$ and was still raised $(7.5 \pm$ $0.3 \mathrm{mmol} / \mathrm{l})$ at $120 \mathrm{~min}$ post-prandially.



Fig. 2. Log plasma CPR concentration (mean \pm SEM) in the hypoglycaemia and control studies. The effective detection limit of the assay is marked as a horizontal dotted line $(0.06 \mathrm{nmol} / 1)$. Hypoglycaemia,

In the control study the mean blood glucose concentration of the same subjects reached a peak value of only $5.1 \pm 0.2 \mathrm{mmol} / \mathrm{l}$ at $30 \mathrm{~min}$ after the meal and regained the fasting level $(3.6 \pm 0.3 \mathrm{mmol} / \mathrm{l})$ by $60 \mathrm{~min}$ post-prandially. The difference in the mean blood glucose concentrations following the meal between the two studies was highly significant at 30,60 and $120 \min (\mathrm{p}<0.001)$.

\section{Plasma C-peptide}

In the hypoglycaemia study the mean plasma CPR fell rapidly after administration of insulin from a fasting level of $0.39 \pm 0.04 \mathrm{nmol} / \mathrm{l}$ (range 0.20 to 0.69 $\mathrm{nmol} / \mathrm{l}$ ) to the effective detection limit of the assay, $60 \mathrm{~min}$ after the injection of insulin (Fig. 2). It remained low throughout the period of blood glucose recovery and at $210 \mathrm{~min}$ after insulin was only $0.11 \pm$ $0.03 \mathrm{nmol} / \mathrm{l}$. CPR levels rose following the meal reaching $1.72 \pm 0.24 \mathrm{nmol} / 1$ at $60 \mathrm{~min}$ and $2.58 \pm$ $0.47 \mathrm{nmol} / 1$ at $120 \mathrm{~min}$ post-prandially.

In the control study, mean plasma CPR rose from $0.35 \pm 0.01 \mathrm{nmol} / 1$ to a peak of $1.76 \pm 0.08 \mathrm{nmol} / 1$ at $30 \mathrm{~min}$, falling to $1.16 \pm 0.14 \mathrm{nmol} / 1$ at $120 \mathrm{~min}$. The differences in the mean plasma CPR concentrations between the two studies were significant $(p<0.001)$ at 15,30 and $120 \mathrm{~min}$ after the meal.

\section{Plasma Insulin}

In the hypoglycaemia study the expected rise in plasma IRI after the injection of exogenous insulin was observed (Fig. 3), and was followed by an expo- 
nential fall. At the time of the meal the plasma IRI had returned to the fasting level. After ingestion of food, mean plasma IRI rose from $8.3 \pm 1.3 \mathrm{mU} / 1$ to $81.6 \pm 12.7 \mathrm{mU} / 1$ at $60 \mathrm{~min}$ and $123.5 \pm 14 \mathrm{mU} / 1$ at $120 \mathrm{~min}$.

In the control study, the mean plasma IRI rose from $9.1 \pm 0.6 \mathrm{mU} / 1$ to $72.4 \pm 0.5 \mathrm{mU} / 1$ at $30 \mathrm{~min}$, falling to $51.0 \pm 7.2 \mathrm{mU} / 1$ at $60 \mathrm{~min}$ and $29.5 \pm$ $4.5 \mathrm{mU} / 1$ at $120 \mathrm{~min}$. The differences in plasma IRI between the two studies were statistically significant $(\mathrm{p}<0.001)$ at all four times of measurement after the meal.

\section{Discussion}

The value of the CPR assay as an index of endogenous insulin secretion is now well recognised [3-6]. The plasma IRI concentrations after the administration of endogenous insulin closely resemble those reported by Garber et al. [10] and had fallen to within the fasting range prior to ingestion of the meal. The decline in the mean plasma IRI concentration during recovery from hypoglycaemia was not however comparable with the marked fall in plasma CPR concentration to undetectable levels, and is inconsistent with the short half-life of insulin in plasma. Appropriately low levels of plasma IRI were observed in three subjects with concentrations falling to less than $6.0 \mathrm{mU} / 1$ by 150 minutes after the administration of insulin, but we are unable to explain the overall discrepancy between mean plasma IRI and CPR concentrations prior to the meal. The prolonged suppression of plasma CPR concentration following hypoglycaemia is consistent however with the observations of Horwitz et al. [3].

The demonstration in man of impaired tolerance to oral glucose following the administration of insulin has previously been described [11] and attributed to the presence of insulin antagonists. The response of the pancreatic beta cell to the ingestion of food following hypoglycaemia has not been reported. The present study shows that following recovery from hypoglycaemia, insulin secretion in response to a meal is abnormal and is associated with impaired carbohydrate tolerance. The initial delay in the secretion of insulin after hypoglycaemia must be partly responsible for the elevated post-prandial blood glucose concentrations. The hypersecretion of insulin observed 120 minutes after the meal may be a direct response to sustained hyperglycaemia.

The mechanism underlying the abnormal secretion of insulin in response to a meal after hypoglycaemia has not been elucidated. The possibility that insulin directly inhibits its own secretion has been studied by maintaining euglycaemia with a glucose infusion during the administration of insulin [12-14]. Partial suppression of CPR levels without hypoglycaemia was interpreted as evidence for the existence of such a direct negative feedback $[12,13]$ but this was not confirmed by Shima et al. [14]. Plasma catecholamines, which inhibit insulin secretion and rise markedly during hypoglycaemia [10], could also cause pancreatic beta cell suppression. The pattern of insulin secretion in the present study is similar to that observed during and after the infusion of adrenaline, where insulin secretion is suppressed until adrenaline is discontinued $[15,16]$; insulin secretion is initially delayed during the recovery period but subsequently hypersecretion of insulin is observed. The early inhibition of insulin secretion after food ingestion could be explained by altered function of the enteroinsular axis following hypoglycaemia. Plasma gastroinhibitory peptide and pancreatic polypeptide levels rise during hypoglycaemia $[13,17,18]$, but the response of those hormones to the subsequent ingestion of food is not known. Finally, the secretion of insulin could be inhibited by a direct effect of hypoglycaemia on the metabolism of the beta cell.

Acknowledgements. We are indebted to Mrs N. Christie, Miss C. A. MacKechnie and Miss S. Taylor for expert technical assistance, and Professor J. A. Strong for helpful criticism and encouragement.

\section{References}

1. Turner R C, Johnson P C (1973) Suppression of insulin release by fish-insulin-induced hypoglycaemia: with reference to the diagnosis of insulinoma. Lancet I: 1483-1485

2. Turner RC, Oakley NW, Nabarro JDN (1973) Changes in plasma insulin during ethanol-induced hypoglycaemia. Metabolism 22: 111-121

3. Horwitz D L, Rubenstein A H, Reynolds C, Molnar GD, Yanaihara N (1975) Prolonged suppression of insulin release by insulin-induced hypoglycemia: demonstration by C-peptide assay. Horm Metab Res 7: 449-452

4. Horwitz D L, Kuzuya H, Rubenstein A H (1976) Circulating serum C-peptide: A brief review of diagnostic implications. N Engl J Med 295: 207-209

5. Service FJ, Horwitz D L, Rubenstein A H, Kuzuya H, Mako ME, Reynolds C, Molnar GD (1977) C-peptide suppression test for insulinoma. J Lab Clin Med 90: 180-186

6. Rubenstein A H, Steiner D F, Horwitz D L, Mako ME, Block MB, Starr J I, Kuzuya H, Melani F (1977) Clinical significance of circulating proinsulin and C-peptide. Recent Prog Horm Res 33: $435-468$

7. Hill JB, Kessler G (1961) An automated determination of glucose utilising a glucose-oxidase-peroxidase system. J Lab Clin Med 57: 970-980

8. Heding LG (1975) Radioimmunological determination of human C-peptide in serum. Diabetologia 11: 541-548

9. Ashby J P, Speake R N (1975) Insulin and glucagon secretion from (isolated islets of Langerhans:) the effects of calcium ionophores. Biochem J 150: 89-96 
10. Garber A J, Cryer P E, Santiago J V, Haymond MW, Pagliara A S, Kipnis D M (1976) The role of adrenergic mechanisms in the substrate and hormonal response to insulin-induced hypoglycaemia in man. J Clin Invest 58: 7-15

11. Somogyi M (1951) Effect of insulin hypoglycaemia on alimentary hyperglycaemia. J Biol Chem 193: 859-865

12. Liljenquist JE, Horwitz D L, Jennings A S, Chiasson J L, Keller U, Rubenstein A H (1978) Inhibition of insulin secretion by exogenous insulin in normal man as demonstrated by $\mathrm{C}$ peptide assay. Diabetes 27: 563-570

13. Service JF, Nelson R L, Rubenstein A H, Go V L W (1978) Direct effect of insulin on secretion of insulin, glucagon, gastric inhibitory polypeptide and gastrin during maintenance of normoglycemia. J Clin Endocrinol Metab 47: 488-493

14. Shima K, Moroshita S, Sawazaki N, Tanaka R, Turui S (1977) Failure of exogenous insulin to inhibit insulin secretion in man. Horm Metab Res 9: 441-443

15. Robertson R P, Porte D Jr (1973) Adrenergic modulation of basal insulin secretion in man. Diabetes $22: 1-8$
16. Turner R C, Hart G, London D R (1977) Suppression of basal insulin secretion by adrenalin in normal man and in patients with insulinomas. Diabetologia 13: 19-23

17. Adrian TE, Bloom S R, Besterman H S, Barnes AJ, Cooke T JC, Russell R CG, Faber R G (1977) Mechanism of pancreatic polypeptide release in man. Lancet I: 161-163

18. Floyd JC, Fajans SS, Pek S, Chance RE (1977) A newly recognised pancreatic polypeptide: Plasma levels in health and disease. Recent Prog Horm Res 33: 519-570

Received: July 4, 1979,

and in revised form: November 30, 1979

Dr. B. M. Frier

Metabolic Unit

University Department of Medicine

Western General Hospital

Edinburgh EH4 2XU

Scotland 